Pathogeny of the Morbid States or Disordered Actions, in certain Parts of the Nervous System.

This final problem is one not peculiar to chorea ; in essence, at all events, it is similar to that which requires solution in many other cases where abnormal blood-states favour the occurrence of local lesions. There are, as we all know, seats of election-that is, particular tissues are apt to become the seats of inflammation, or some other pathological change in different diseases. In typhoid fever, the small intestine is gravely affected; in scarlet fever, the throat and tonsils suffer; in rheumatic fever and other states, the endocardium of particular parts of the heart inflames, just as in lead-poisoning, particular muscles of the body are especially implicated. It seems to me, therefore, a fact of the same order when we find that a certain altered blood state predisposes certain individuals not only to a subacute endocarditis, but to an irritation of certain specially active parts of the brain, which goes on to produce what we may call a subacute inflam. mation.

The intimate processes of nutrition in different tissues of the body and in different parts of the same anatomical system, must vary with the chemical composition of such tissues, and is, in all probability, subject to variation under influences which cannot be thus roughly expressed. Hence, a certain blood-state differing from that which is habitual to the individual may easily pass beyond the range of what is compatible with the continuance of an ordinary nutritive and functional activity in the elementary parts of certain tissues. Such tissue-elements become "irritated" (what other word can we use ?) and begin to attract more blood. In this we have a state corresponding with what I apprehend to be the first stage of the perverted function which shows itself in the corpora striata and adjacent parts at the commencement of chorea ; though, as I have already hinted, a somewhat similar condition may be brought about in different ways, and sometimes would seem to be occasioned by the direct action of fright (Para2ysis from Brain-Disease, pp. 27-30). At other times, indeed, no distinct cause, either predisposing or exciting, can be assigned (as with other nervous diseases of the same class), though such instances are frequently ascribed to some source of "reflex irritation". But, howsoever induced, if the irritation continue, the disturbed action outside the vessels communicates itself to the tissue elements inside the vessels, as they come within the morbid area. The white corpuscles, as a consequence, begin to adhere to the walls of the small vessels, so that partial obstructions may be produced, which are, perhaps, thereafter rendered complete by separation of fibrine or allied products. And in certain exceptional cases, such as those which have been encountered by Dr. Aitken and Dr. Tuckwell, small foci of softening may be produced.

After detailing the results of his own observations, Dr. Dickinson writes (loc. cit., p. I6). "Arterial repletion seems mainly concerned in the development of the disease ; why, or at what bidding do these vessels thus gorge themselves?" The answer which I should be in. clined to give to this question has now been briefly sketched, and I am pleased to find that, in many respects, Dr. Dickinson's interpreta. tion does not very materially differ therefrom.

Multiple occlusions of capillaries and small vessels may easily give rise to the minute vascular injections which have now, on so many occasions, been met with in the corpora striata and adjacent parts of the brain in fatal cases of chorea (see Pathological Transactions, 1869, p. I5). It is, however, especially needful in an affection of this kind in which the only easily recognisable post mortem mark is one of hyperæmia, not to confound that which lies at the root of the disease with other hyperæmias more or less secondary in their duration and mode of origin. Certainly, this is a point which should be carefully borne in mind by future investigators.

In brief, then, my view of the etiology and pathology of chorea is this. In common with many who have spoken with greatest authority on this subject, I look (certain rare cases excepted) to an altered and often anæmic blood-state as its predisposing cause in individuals of a certain age and nervous temperament. Secondly, I look to the initiation in such individuals of a disturbed nutrition in the corpora striata and adjacent parts of the brain, tending to issue, and often actually issuing, in what, for want of any other more appropriate term, may be called a subacute inflammation of these centres-often characterised in part by the production of multiple minute thromboses. It will be seen, therefore, that I hold no simple theory which can be embodied in a single phrase, though, as regards the great majority of cases of chorea in which there are local lesions-and these are well marked-it is quite true that I would replace the embolic theory by what Dr. Hughlings Jackson has termed the "hypothesis of thrombosis".

\section{CONSUMPTION AND CLIMATE.}

By RICHARD PAYNE COTTON, M.D., F.R.C.P., Consulting-Physician, and late Senior Physician, to the Hospital for Consumption, Brompton.

Dr. Reeves of Melbourne, in his recently published work on Consumption in Australia," has, I think, done us a real service. He shows what, I suppose, all of us were well prepared to hear, that phthisis is scarcely less frequent and fatal in Australia than in England ; and that, however modified the disease may be at our antipodes, it is nevertheless there, ever ready to claim its victims, and to show us that there is no exception in that country to the universal presence of that dread malady. And yet how many of us are in the habit of sending certain of our phthisical patients to Australia, and of finding that, however often the result may have been unsatisfactory, yet, in many instances, our best hopes have been even more than realised.

Some years ago, I was consulted by a young medical friend, already decidedly phthisical, about his settling in Australia. He went there with my approval, and is now one of the most successful medical practitioners in the colony, and occasionally sends me a letter, saying that now he can equally well both see his patients and hunt the kangaroo. Several similar, and quite as promising cases have at various times come before me ; but circumstances have not permitted me to trace for any length of time their subsequent histories.

On the other hand, and quite in accordance with Dr. Reeves's statements, our confrères in Australia not unfrequently send their native consumptive patients to be cured in England. Two such examples have lately fallen under my own observation; in the one, the change was productive of the happiest results ; in the other, however, the disease ran on with unchecked rapidity.

How are such circumstances reconcilable? Is it not apparent that there cannot exist, either in the one locality or the other, any special or specific influence, and that any benefit to be derived in either instance must be due to other causes? Whether the tubercular diathesis arises here or in any foreign climate, a change from that climate and from every circumstance of life connected with it, a rest from the work and conditions under which it has arisen, a new field of occupation and thought, and especially, as in our relation to Australia, where all this is prefaced by a long sea-voyage, constitute, indeed, the real and only active influences for good.

Early cases of phthisis, more especially those of a strongly inherited origin, where the pulse is not much quickened; the breathing calm; where there has been no recent and never any active hæmoptysis; cases of the "languid" rather than the "florid" type of the disease present the conditions upon which the changes I have just enumerated would be the most likely to tell, and upon which they certainly often do tell very satisfactorily.

And here, in connection with this subject, I would make a passing remark upon the now rapidly dying out opinion, that there is anything in any one climate, wherever it may be, which is opposed to the development or even the increase of tubercular disease. Consumption exists everywhere. There is no favoured spot where it is not. There is no "promised land" for our consumptive sufferers, where they will fail to meet with native consumptive sympathizers.

It is quite true that the form of tubercular diseases, their degree, severity, and duration, may differ considerably in different parts of the world, according to the habits of the people, and the relation of the climate to such habits; but there is no favoured country where tubercle has not a birth-place. Trouble, privation, numerous sources of unhealthiness uncontrolled, and many perhaps uncontrollable, the evil habits of civilised life, the vices of individuals and of society, have, unhappily, no geographical limit, but are everywhere exercising their influence, although, of course, in differing degrees, both in originating and arousing tuberculous diseases. Consumption's old and special title of "English disease" is as undeserved as it used to be common.

Some years ago (Fothergillian Prize Essay), I published the result of numerous inquiries on this subject. I found that, everywhere, whether in cold, temperate, or hot climates, consumption was known only too well by my professional brethren. Dr. Wilson of New Brunswick stated that "the great majority of the adult aborigines of North America died of phthisis, and that the disease is very common amongst European settlers".

In more temperate climates-take, for instance, the very healthresorts of the consumptive invalid-the shores of the Mediterranean, Italy, the South of France, Spain, and Portugal-phthisis is to be found. Dr. Burgess says (Lancet, July 1850): "There is no part of * Reviewed in British Mrdical Journal, Decmmbe 3oth, 1876 . 
France where consumption is so prevalent amongst the native population as at Montpelier and Marseilles." Dr. Journée's tables upon phthisis in Italy show that the same is the case in that country. Dr. Meryon (Lancet, July I850) says : " Had I leisure, I could collect facts to prove that there are more natives (not strangers, but born and bred in the place) who die of consumption in Nice than in any town in England of the same amount of population." My colleague Dr. Pollock, who practised for many years in Rome, states that, "in no country is consumption so rapidly fatal as in Genoa, Florence, and Naples" (Medical Gazette, vol. xlvi). Madeira itself, so long the "city of refuge" of our phthisical countrymen, forms no exception. Dr. Mason says that consumption and scrofula are frequent there (Climate and Meteorology of Madeira). The late Sir Ranald Martin, so long distinguished as a surgeon in India, once assured me that, in the East Indies, both native and European residents are often attacked with phthisis. The late Dr. Musgrave of Antigua has often told me that, in the West Indies, many of the native blacks fall victims to consumption.

And yet, as in the case of Australia, we send, and wisely so, many of our properly selected consumptive patients to the South of France, Italy, Algiers, etc. As with Australia, however, we must not promise them that they will meet there with anything specific. We can only hope that the rest and change, the milder air permitting more outdoor exercise than in England-the variety, in fact, offered to them in their every work and thought--may induce, according to their individual requirements, either some peaceful respite or some healthful reaction.

\section{NOTES OF A VISIT TO THE MILITARY HOSPI- TALS OF THE CONTINENT.}

By ALBERT A. GORE, M.D., Surgeon-Major, Dublin.

II.-BRUSSELS.

ThE military hospital is in the Rue des Minimes, and was formerly a convent, erected in 1725. It is in an old part of the town, and not far distant from the Hôtel de Ville, in the front room of which the Emperor Charles V signed his abdication. Like most old buildings of that date, the shape is quadrangular, with a courtyard in the centre, and a garden attached. The hospital is visited at 9 A.M., and a saur de charité is on duty in each of the four divisions, and appears to have much to do in the nursing as well as in the looking after the wants of the sick.

The construction of this old building (in the wards of which it is not improbable that many of our wounded soldiers were received after the battle of Waterloo) does not admit of cross-ventilation, as the wards open upon corridors, in some of which were rows of beds. The walls were scrupulously clean and neat, and the walls limewashed. The hospital contains two hundred beds, and takes the sick of the garrison of Brussels, numbering between 2,500 and 3,000 men. It is divided into wards for officers, non-commissioned officers, and privates. Venereal cases, febrile diseases, psora, eye-cases, and surgical affections are treated separately. The walls of the ophthalmic ward, which, on August 26th, only contained three patients, were not coloured. The patients seemed upon the whole anæmic; especially those suffering from secondary venereal affections, which were treated in great part by mercury.

In the garden is the pharmacy, in charge of a chief chemist, who wore a decoration in his button-hole, and two assistant-chemists, with three or four subordinates, and fourteen students in pharmacy. There was also in the enclosure a wooden hut (limewashed on the inside), and intended for the reception of small-pox cases and other infectious disorders. In the same building with the pharmacy were the quarters of the two junior medical officers ("médecins-adjaints", or assistantsurgeons), and those of the administration-director, or intendant, who distributed the rooms, and looked after the diet, clothing, hospital stores, and the ventilation of the wards. Further behind is the mortuary. Each of the resident assistant-surgeons had a large sittingroom, off which were two closets; one of them was used as a bedchamber, the other as a dressing-room.

Antwerp has the largest military garrison in Belgium; but Brussels, the capital, is the head-quarters of the medical staff of the Belgian army. Dr. Fromont is "Inspecteur-General du Service de Sante de l'Armée", and is assisted by a médecin-principal of the second class as assistant inspector-general, a second assistant or battalion surgeon of the second class, and a pharmacien. The army (including the reserve) numbers 104,000 men, 16,000 horses, and 210 guns. Upon a black board in the consulting-room of the hospital are the names, rank, and addresses of the officers constituting the medical staff of the garrison hospital, of which M. Lelong, medecin-principal of the first class, is chief. There are, in addition, two assistant-surgeons, three chemists, twenty-six students in medicine, and fourteen students in pharmacy. The regimental medical staff of the garrison numbers four first class, or regimental surgeons-major; eight battalion-surgeons, and a proportion of assistant-surgeons. Each battalion of infantry is three hundred and twenty strong. The medical officers all wear the same uniform, with the distinction of rank in the képi and sleeve, as in the French service. A very large proportion of the military surgeons are in private practice in Brussels. Dr. Lelong is Physician to the Count of Flanders, and to many of the nobility; a considerable number of the senior officers are decorated.

The case of each patient is taken at his bedhead on two forms or modèles. The first of these is a "liste des médicaments" prescribed ; and the other a clinical memoir (jour par jour). At the expiration of every half-year, a manuscript report is made of the diseases and injuries treated in the hospital; the principal record.

To the medical officer on duty $I$ an indebted for the following interesting particulars. During the six months ending Dec. 31st, 1875, there had been admitted to hospital 846 patients, of whom I4 died. The admissions were : venereal, I43; ophthalmia, 38 ; wounds and injuries, 388 ; fevers and medical diseases, 382 . Of the medical cases, 328 were acute and 54 chronic. Of 1,007 patients (846 admitted and $16 \mathrm{I}$ remaining on June $30 t h), 76 \mathrm{I}$ were discharged cured, 39 were sent to the depôts of their corps with certificates of invaliding, 56 obtained convalescent leave to go home, and 5 were sent to the special ophthalmic hospital at Louvain; 14 died, and 132 remained under treatment on December 3 Ist.

During the first six months of 1876 , there were admitted to hospital 932 patients ; 132 remained under treatment, 56 of the admissions were conscripts under observation.

Admissions.-Fevers and other medical diseases, 455 ; wounds and accidents, 26I ; ophthalmia, 49 ; venereal, 167. Varieties of venereal disease-balanitis, 10 ; posthitis, 2 ; phimosis, 2; paraphimosis, 2 ; urethritis, 93 ; stricture, 2 ; cystitis, 1 ; orchitis, 1o ; chancre, 33 ; constitutional syphilis, 5 ; warts, 6 ; nodes, $\mathrm{I}$.

The public women are examined twice a week in Brussels.

From the total, 1, $06_{4}$, occurred 22 deaths, viz: typhoid fever, 13; consumption, 4 ; cerebro-spinal meningitis, 1 ; acute tuberculosis, I; peritonitis, I ; general abscess, I ; fracture of base of skull, I.

The troops of the line in Belgium appear to be as a rule very young lads, clothed in blue coats with red shoulder-knots, and linen trousers. The men of the guard corps are taller.

Patients in hospital are given bread and milk at 7 A.M. ; soup, bread, and fresh meat at IO A.M.; and a mess of vegetables and some bread at 4 P. M., with any extras ordered by the physicians. The hospital contains six baths, three of which were devoted to cases of psora, which were treated by the sulphur and lime method. The hospital clothing is dark blue.

[To be concluded.]

\section{CASE OF ESOPHAGEAL FISTULA OPENING THROUGH THORACIC PARIETES LATERALLY.}

By J. G. SINCLAIR COGHILL, M.D.,

Physician to the Royal National Hospital for Consumption and Diseases of the Chest, Ventnor.

THIs morbid condition is, so far as I am aware, of such extremely rare occurrence, that a brief report of the case may be of interest.

J. B., aged 33, a printer, enjoyed good health until February 1875 , when he had, to use his own words, congestion of the lungs and pleurisy. An abscess formed on the right side, pointed, and was opened in June; since then four other openings were made, the last two in November, when drainage-tubes were introduced. He had been under treatment in the Great Northern Hospital, and on the 27th of April, his schedule, as filled up by Dr. Frederick A. Carter, describes his condition as follows : “Empyema of fifteen months' duration, discharging slightly at the present time through two drainage-tubes, unconnected, one in each of two openings. By percussion there is noted some slight loss of resonance at both apices, and on auscultation air is found to enter both lungs fairly well and no rales to be heard. Height 5 feet 10 inches; pulse 108; respirations 15, and natural. There is no family history indicating hereditary proclivity."

He was admitted into the Royal National Hospital here on May 22nd, and the following notes are taken from the case.book, entered 